\section{Nestlé moves into gut microbiome tests}

Swiss food giant Nestlé has entered a partnership with French biotech Enterome Biosciences to develop microbiome-based diagnostics for inflammatory bowel disease (IBD) and non-alcoholic fatty liver disease (NAFLD). The Microbiome Diagnostic Partners (MDP) announced on July 11 consists of a $50 / 50$ joint venture between the Paris-based Enterome and Nestlé Health Science, the Epalinges, Switzerland-based Nestlé subsidiary. Nestlé will invest $€ 20$ (\$22.8) million in the MDP, and Paris-based Enterome will grant exclusive rights to its microbiome profiling tests in all areas except immuno-oncology. Enterome has a collaboration with New York-based Bristol-Myers Squibb in this area, to identify lung cancer patients who, depending on their microbiome composition, might be sensitive to checkpoint inhibitor Opdivo (nivolumab) (Nat. Biotechnol. 35, 5, 2017). For the new joint venture, the IBD programs will be based on Enterome's biomarker IBD110, a gut microbiome biomarker of mucosal healing (Nat. Biotechnol. 35, 9, 2017) and MET210 as a biomarker for NAFLD. In April 2016, Nestlé formed part of a $\$ 14.5$-million series $C$ round to develop Enterome's EB 8018 — a novel smallmolecule FimH antagonist that targets adherent invasive Escherichia coli proliferation in the gut, one of the main causes of IBD.

Nestlé gains options to exclusively license rights to commercialize the two initial programs, and Nestlé's diagnostics subsidiary, San Diegobased Prometheus Laboratories, will bring in development and commercialization expertise to MDP to develop a biomarker and diagnostic.

Also on July 11, Google-backed Cambridge, Massachusetts-based Evelo Biosciences raised a total $\$ 100$ million with plans to begin five to ten clinical trials of monoclonal microbesspecific single strains of naturally occurring microbes-in 2018, followed by licensing a microbiome-based cancer immunotherapy from the University of Chicago in April 2016

C.We haven't done a single financing round without having to show data on our assay. That's largely been because of Theranos." Gabe Otte, CEO and co-founder of diagnostic company Freenome, remarks on the legacy left by Theranos, which raised hundreds of millions of dollars without showing any data before it crashed and burned. (Wired, 2 August 2017)

"Their value as human beings is profoundly denigrated every time they are created, experimented upon, and then killed. Moreover, if such embryos were to grow up, as will doubtless occur in the future, there are likely to be unintended effects from modifying their genes." Reverend Tadeusz Pacholczyk of the National Catholic Bioethics Center reacts to the news that researchers had edited a gene in human embryos. (GEN, 4 August 2017)

\section{CRISPR patent estate splinters}

The long-running CRISPR-Cas9 patent dispute over rights to the lucrative gene-editing tool has taken a new turn with the European Patent Office announcing its intention to award Merck KGA a patent for the technology. At the same time, the battle for ownership between the University of California (UC) and the University of Vienna, on the one side, and the Broad Institute and its partners, on the other, is nearing a conclusion. On July 25, lawyers for Jennifer Doudna, of UC Berkeley, and Emmanuelle Charpentier, formerly of the University of Vienna, lodged an appeal with the US Patent and Trademark Office (USPTO) seeking to reverse a February 17 ruling that there was no interference between their patent claims and those from the Broad, based on Feng Zhang's research at the Cambridge, Massachusetts institute. The Broad Institute is due to submit its counterargument by October 25. But the European Patent Office's decision to grant the Merck KGA subsidiary MilliporeSigma a patent makes a single winner now seem unlikely. And in the long term, as the technology evolves, novel endonucleases and various flavors of CRISPR could evade even the broadest patent claims.
The lawyers representing the CharpentierDoudna side face a difficult battle, as they need to convince the appeal court judges that the original USPTO appeal board's decision was legally flawed. "They are seeking to determine if there was an error in the application of the law," says Mike Fuller, chair of the biotech practice group at Knobbe Martens, an intellectual property law firm based in Irvine, California. It is rare, however, for appeal judges to overturn the board's rulings. "They give a lot of deference to the decisions of the patent office," Fuller says. Once the lawyers have completed their work, executives at the various companies associated with the two camps will likely hammer out a cross-licensing agreement.

Charpentier's and Doudna's companies, already share much of their intellectual property (IP) estate. Charpentier co-founded Zug, Switzerland-based CRISPR Therapeutics and Dublin-based ERS Genomics, and Doudna co-founded Cambridge, Massachusettsbased Intellia Therapeutics and Berkeley, California-based Caribou Biosciences. The companies recognize each other's IP rights and cooperate on maintaining those patents that are shared by Cambridge-based Editas

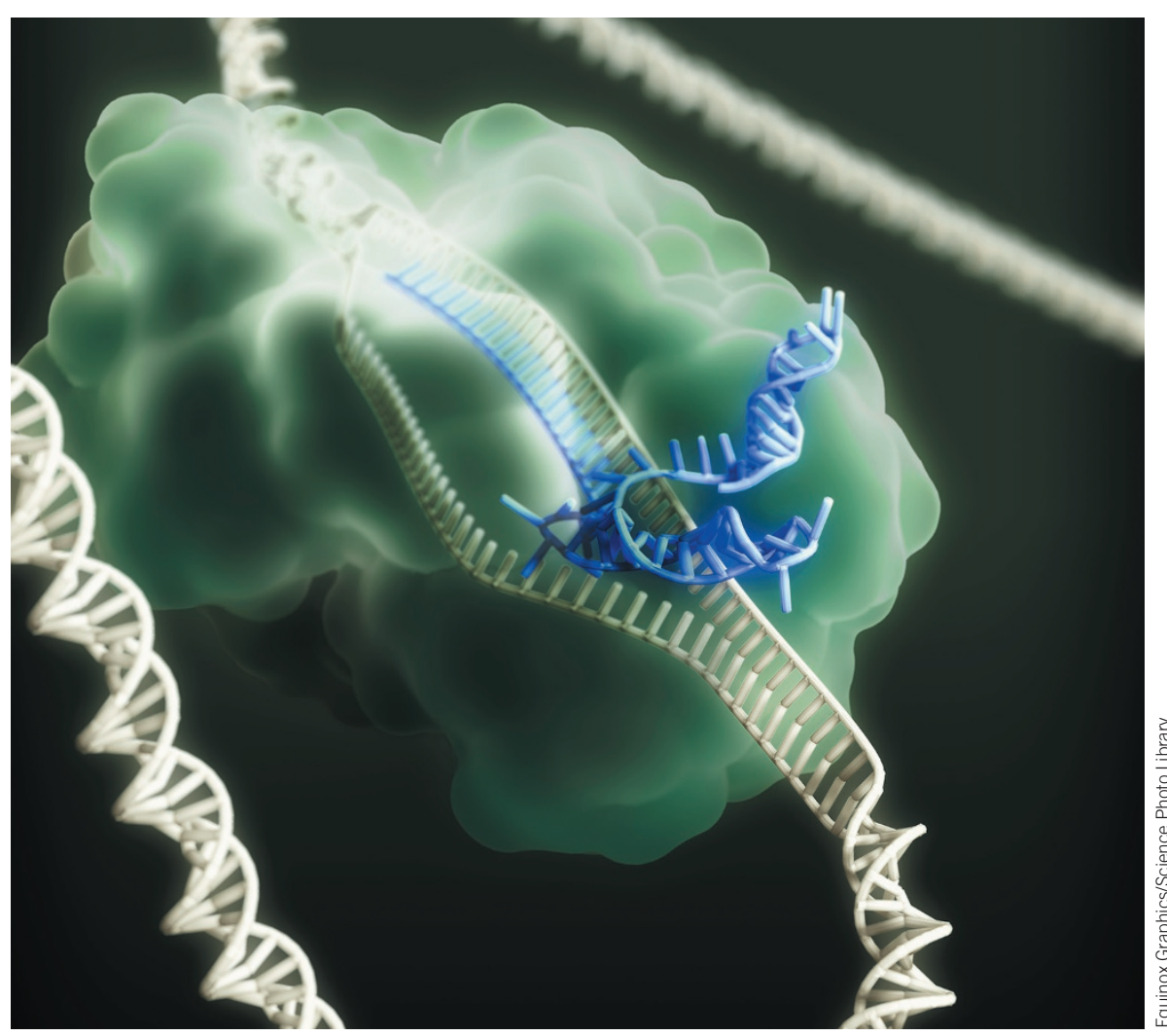

CRISPR-Cas9 gene editing a complex, molecular structure. The Cas9 protein is shown in green, the guide RNA is blue, and the double strand of the DNA is shown as a helical structure. 